\title{
HISTORICAL ASPECTS OF STUDYING THE INFLUENCE OF PHYSICAL ACTIVITY ON THE MENTAL HEALTH OF PEOPLE
}

\author{
Sergii Ivashchenko \\ Boris Grinchenko Kyiv University, Kyiv, Ukraine
}

UDK 796, 4 (477)

\section{SUMMARY}

This article presents the main results of work on the study of the issue of the historical process of improving knowledge about the influence of physical activity of a person on the level of his mental health.

Based on the results of the analysis of scientific information presented in modern domestic and foreign literary sources, the conclusion was substantiated that the historical process of improving knowledge about human nature and his mental activity in recent years has reached the highest level of development.

The study of the long-term experience of scientists in many countries of the world gives grounds to assert that the beginning of the process of targeted study of the effect of physical activity on human mental functions was laid back in the last century. However, scientists have achieved the most outstanding results in this area of scientific research in recent decades.

The historical need for in-depth research in this scientific direction was maturing gradually and was due to the peculiarities of the course of scientific and technological progress in general.

Due to the fact that it was in recent decades that many discoveries were made, which formed the basis of modern methods for studying the physiological state of a person and his intellectual functions, there was obvious progress in the study of the mental health of persons whose central nervous system works under conditions of extreme intellectual and psycho-emotional stress.

Scientists working in the field of physical education and sports, in collaboration with scientists in the field of education and health, have significantly intensified their joint activities and developed modern complexes of measures aimed at studying the mental health of students and representatives of the teaching staff of state institutions of higher education. 
This contingent of the subjects was not chosen by chance. The fact is that the learning process in higher education institutions is associated with intense loads on the central nervous system of both students and teachers, as well as on some of their senses (in particular, on the visual and auditory analyzers).

Keywords: central nervous system, intellectual stress, cognitive functions of the brain, level of mental health.

\section{INTRODUCTION}

In the historical aspect, the development of knowledge about the role of physical fitness and health promotion, designed for different categories of the population, was very important ${ }^{1}$.

The implementation of such work formed the basis of theoretical data on the indicators of human mental health with the level of physical development and the nature of physical activity.

Thus, there was a need for such a way to further improve the existing systems of physical training for different groups of the population, which would provide a positive effect of these systems on the psycho-emotional state of people. At the same time, the main task of physical education of the population remained to achieve optimal indicators of physical development of people and normalize the cognitive functions of their brain².

The practical solution of this extremely complex and important scientific problem required the joining of efforts of leading specialists who are experts in the field of human physiology, the organization of the process of physical education of the population and the protection of their health.

However, thanks to the coordination of the efforts of these specialists, this problem was successfully solved in most countries of the world. But in many countries, the process of finding optimal ways to solve this problem, taking into account all the physiological characteristics of the inhabitants and their national psychology, continues in our time.

It should be noted that the gradual progression of the development process concerning the doctrine of the influence of the person's motor activity was very slow.

\footnotetext{
1 Zivanovic, Nenad; Antala, Branislav; Pantelic-Babic, Kristina.(2015): The History of Physical Education in Europe, Book 1-2, FIEP Europe - History of Physical Education and Sport Section, Faculty of Physical Education and Sport, Leposavic, Serbia.

2 Avramovic, Z. (2011): Sociological Wahchtower of Culture and Education, Raska Skola, Belgrade.
} 
Especially about main indicators of people's mental health and the degree of development of the main cognitive functions of his central nervous system.

Such situation has led to the need to create a unified strategy regarding the ways of translating the main provisions of this theory into the practical activities of physical training the population.

At the same time, the process of progression of this teaching took place unevenly in different countries, and this was due to the unevenness of the levels of technical and economic development of different countries.

The logical result of the implementation of the provisions of this teaching was a positive impact on the indicators of people's mental health.

In addition, the results of statistical studies showed that it was in those regions where measures to implement the provisions of this doctrine were especially effective that the number of seeking medical help due to impaired well-being and basic cognitive functions of the brain (attention, memory, orientation in the environment etc.)

A thorough analysis of the information presented in modern sources of scientific literature convincingly indicates that in our time the issue of continuing the historical process of improving the theory about the influence of the nature of a person's motor activity on his consciousness and mental functions remains extremely relevant.

Over the past decades, scientists from many countries have carried out a significant amount of fundamental scientific research, the main goal of which was to find optimal ways to solve urgent problems of the further development of systems of physical education of people ${ }^{3}$.

In the course of their research, extremely important information was obtained by those scientific institutions and individual scientists who were engaged in determining the influence of certain types of physical activity on the indicators of physical and mental health of people.

Many of these scientists came to the conclusion that the correct application of modern physical training programs stimulates the development of certain spiritual and psychological properties in people.

According to many well-known scientists who have achieved outstanding results in studying the influence of external factors on human health, circumstances such as optimal living conditions from a hygienic point of view, rational preventive nutrition and the correct mode of physical activity, contribute

\footnotetext{
3 By Martin-Storey and Crosnoe, Robert, "Trajectories of overweight and their association with adolescent depressive symptoms", Health Psychology 34 - 10 (2015): 1004 - 1012.
} 
to the improvement of the psychological state of the individual and the development of his mental qualities ${ }^{4}$.

Despite the achievement of significant results in the development of the physical and spiritual state of people, questions about the impact of certain motor stereotypes on the functions of the central system.

Therefore, the continuation of work in this direction of scientific research is relevant and intriguing for many scientists of the world. Including this situation is the basis for the creation of this scientific article 5 .

\section{METHODS}

During the implementation of the activities provided for in the plan of this study, we used several scientific methods.

First of all, this is a method of studying domestic and foreign scientific literature, a method of historical analysis of the problem under study, a review method, a method of expert assessments and a method of statistical processing of the data obtained.

Finally, to form well-grounded conclusions, the classical comparative method was used, which made it possible to present the dynamics of the process of studying this problem in a historical aspect.

To carry out this study, two separate stages of its activities were used. The first phase lasted for one year from February 2009 to February 2010.

During this period, we conducted a number of studies aimed at studying the indicators of mental health of students of higher education institutions in the city of Kiev, as well as studying the main cognitive functions of the central nervous system of these students.

During the second period of this study, which lasted from February 2019 to February 2020, the previously mentioned studies of mental health and cognitive functions of students were repeated.

Finally, all the data obtained were statically processed using modern mathematical methods adapted to the field of medicine and physical education.

\footnotetext{
${ }^{4}$ Antala, Branislav and Jaromir Sedlacek, "International Federation of Physical Education history and the present in Europe", FIEP Bulletin, no.1, vol.83 (2013): 7 - 36

5 Ivashchenko, Sergii, "Historical Preconditions of the Origin of Self-Olympic Direction of Physical Culture in Ukraine”, Physical Education and Sport through the Centuries (2019): Vol. 5 - Issue 2. - P. 36 -42 .
} 
Comparison of the results obtained in the first and second periods of the study allowed us to draw conclusions about the existing trends in the change in the properties of the intellectual activity of young people who are trained in higher education institutions in the city of Kiev.

A thorough analysis of the data obtained in the course of the activities of the first and second stages of this scientific research provides an opportunity to establish the existing dynamics of changes in those indicators that characterize the mental activity of students.

In addition, this information makes it possible to determine which factors and circumstances significantly affect the indicators of mental health and basic cognitive functions of the central nervous system of students.

There is no doubt that one of the most powerful factors of this series is the nature of students' motor activity and their level of physical fitness.

Therefore, the information obtained during the implementation of the activities of this scientific work can be taken as a basis for further deeper study of this scientific problem.

In particular, from a scientific point of view, it would be interesting to receive a detailed description of these indicators from students from other countries in order to perform their comparative analysis and establish the extent to which they are influenced by the national characteristics of the population of a particular country.

\section{RESULTS}

Both in some countries of the world and in Ukraine, attempts to deeply investigate the dependence of the level of human mental health on the nature of his physical activity have been systematically undertaken since the end of the nineteenth century.

This is confirmed by the information contained in certain archival documents and stored in the corresponding funds of archival documents.

However, a more complete implementation of such plans became possible only in our century, since it was in this century that the abrupt development and improvement of technologies necessary for the successful implementation of such research took place.

It should be noted that the rapid development of modern technologies of scientific research took place not only in those centers where there were optimal conditions for scientific and technological progress.

This process took part everywhere on the basis of the involvement of a wide range of healthcare professionals and physical education of the population. 
In the process of carrying out this research work, a large number of documentary sources of information were subjected to study, analysis and generalization.

Based on the results of such a study, it was found that the historical process of studying the relationship between the indicators of mental health and cognitive functions of the human central nervous system proceeded unevenly in different regions of Ukraine.

It was especially successful in those cities where large medical institutions and educational institutions were located, which were used as a base for conducting appropriate clinical studies related to the nature and level of intensity of the educational process ${ }^{6}$.

This pattern could be explained by the fact that in order to conduct fundamental research in the field of human psychophysiology and study the properties of the central nervous system, it was necessary to use special equipment, which in those years was available only in large-scale medical institutions of the regional and republican level.

In addition, the experimental base for such research was a wide contingent of student youth, most of whom underwent planned training at universities, institutes, schools and other educational institutions of the country ${ }^{7}$.

Especially favorable was the situation in which both large medical organizations and institutions of higher and secondary education, in which a large number of students were trained, functioned within the same settlement ${ }^{8}$.

Then a comparison was made of the indicators of mental health and cognitive functions of the brain of students in the first and second periods of the study.

The data obtained as a result of comparing these indicators testified to the progression of the development of cognitive functions and an increase in the integral indicator of the mental health of students who are trained in higher education institutions in the city of Kiev.

Using the method of questionnaires and interviews, we determined the indicators of the mental health of students on the basis of their complaints about the deterioration of health during the first and second periods of the study.

The main complaints were deterioration in mood, sleep disturbances, headache, nausea, dizziness, lack of appetite and others.

\footnotetext{
${ }^{6}$ Rados, Jovo, Ethics in Sport. Kairos, Sremski Karlovci, 2013.

${ }^{7}$ Bradar, Milan, Between the Abyss and the Sky. Institute for Political Studies, Beograd, 2015.

8 Živanović, Nenad; Milošević, Zoran: Physical Culture Between Rationalism and Theoanthropocentrism, Physical education and sport through the centuries 2018, 5(2); P 5 - 16.
} 
We determined the indicators of the students' central nervous system cognitive functions based on the results of their performance of special tests designed to check the state of attention, memory and resistance to stress.

At the same time, we calculated the individual indicators of each student, and also calculated their total and average values, expressed in arbitrary units, or points.

The data, obtained during our investigation, are presented in the table 1 , containing results of the both stages of the study.

Table 1. Indicators of mental health and cognitive brain functions of students

\begin{tabular}{|c|l|c|c|}
\hline № & \multicolumn{1}{|c|}{ Indicator name } & $\mathbf{2 0 0 9}-\mathbf{2 0 1 0}$ years & $\mathbf{2 0 1 9}-\mathbf{2 0 2 0}$ years \\
\hline 1 & Attention indicators & $287,3 \pm 3,8$ & $302,4 \pm 3,9$ \\
\hline 2 & Memory metrics & $312,6 \pm 4,1$ & $326,4 \pm 4,3$ \\
\hline 3 & Indicators of resistance to stress & $188,5 \pm 2,6$ & $204,9 \pm 2,8$ \\
\hline 4 & Integral indicator of mental health & $422,7 \pm 5,8$ & $448,5 \pm 6,1$ \\
\hline
\end{tabular}

As the results presented in this table show, there was a change in all indicators, the study of which was carried out in the first and second periods of work.

In particular, the value of the integral indicators of attention, memory and resistance to stress among students in the second period of studying this problem turned out to be higher than the same indicators among students in the first period of the study.

Comparison of the typical regimen of students' motor activity showed that in the students of the second period of the study, it was more rational in relation to the individual capabilities of each student separately.

\section{DISCUSSION}

Considering the fact that in many countries of the world in our time, much attention is paid to the study of the influence of the nature of human motor activity on the state of his mental health, this study is naturally considered very relevant.

It would be logical to assume that the most important results of such studies would be for students of all categories. In particular, for students of universities and other institutions of the higher education system.

It should be noted that the information obtained in the course of this study convincingly testifies to the high level of significance of the process of optimizing the motor activity of students in order to stimulate their mental functions and increase the level of academic performance. 
That is why in those states where due attention is paid to the problem of improving the system of physical education for various categories of the population, there is a fairly high level of education of young people.

The study of this problem requires deep knowledge in the field of normal physiology, psychology, organization of the educational system, hygiene of human intellectual activity and other sciences.

To obtain reliable information about the influence of the mode of human motor activity on the level of activity of neurons in certain zones of the cerebral cortex of his brain, the use of special equipment and special techniques is required.

From all this, it is easy to conclude that the popularization of a healthy lifestyle and the optimization on a scientific basis of the regulation of human motor activity can positively influence the state of his mental health and stimulate the cognitive functions of his brain.

And this, in turn, is necessary for the successful mastering of curricula by students of higher education institutions in order to acquire knowledge and practical skills that underlie their successful professional activity in the future.

The solution of such a complex and responsible task is extremely important for society as a whole. Therefore, the level of professional competence of specialists looking for ways to solve this problem must be extremely high.

In addition, to conduct constant monitoring of the state of mental health of young people, certain conditions, appropriate equipment, trained specialists and a well-developed system of research are required.

Education in institutions of higher education is a very complex, long and responsible process associated with extreme loads on the central nervous system of students, as well as their visual and auditory analyzers.

That is why a successful solution to this problem is possible only under the conditions of thorough scientific research and coordination of efforts of all specialists working in the field of pedagogy, health care and physical education.

\section{CONCLUSION}

The data obtained in the course of our research provides grounds for the following conclusions:

1. Among all students of institutions of higher education, there is a relationship between the level of optimality of the regime of their daily physical activity and indicators of mental health.

2. Popularization of a healthy lifestyle and optimization of the motor activity regime of students of higher educational institutions can have a 
positive effect on the indicators of the cognitive qualities of their central nervous system.

3. In order to maintain the proper level of mental health of students, it is necessary to develop and implement such educational programs that would be adapted to the potential of the cognitive functions of the central nervous system of students.

\section{REFERENCES}

1. Zivanovic, Nenad; Antala, Branislav; Pantelic-Babic, Kristina.(2015): The History of Physical Education in Europe, Book 1-2, FIEP Europe - History of Physical Education and Sport Section, Faculty of Physical Education and Sport, Leposavic, Serbia.

2. Avramovic, Z. (2011): Sociological Watchtowers of Culture and Education, Raska Skola, Belgrade.

3. By Martin-Storey and Crosnoe, Robert, "Trajectories of overweight and their association with adolescent depressive symptoms", Health Phychology $34-10$ (2015): 1004 - 1012.

4. Antala, Branislav and Jaromir Sedlacek, "Intermational Federation of Physical Education history and the present in Europe", FIEP Bulletin, no.1, vol.83 (2013): 7 -36 .

5. Ivashchenko, Sergii, "Historical Preconditions of the Origin of Self-Olympic Direction of Physical Culture in Ukraine", Physical Education and Sport through the Centuries (2019): Vol. 5 - Issue 2. - P. 36 - 42.

6. Rados, Jovo, Ethics in Sport. Kairos, Sremski Karlovci, 2013.

7. Bradar, Milan, Between the Abyss and the Sky. Institute for Political Studies, Beograd, 2015.

8. Živanović, Nenad; Milošević, Zoran: Physical Culture Between Rationalism and Theoanthropocentrism, Physical education and sport through the centuries 2018, 5(2); P 5 - 16.

\section{ИСТОРИЧЕСКИЕ АСПЕКТЫ ИЗУЧЕНИЯ ВЛИЯНИЯ ФИЗИЧЕСКОЙ АКТИВНОСТИ НА ПСИХИЧЕСКОЕ ЗДОРОВЬЕ ЛЮДЕЙ}

\footnotetext{
АННОТАЦИЯ

В статье представлены основные результаты работы по изучению вопроса исторического процесса совершенствования знаний о влиянии физической активности человека на уровень его психического здоровья.
} 
В результате анализа научной информации, представленной в современных отечественных и зарубежных литературных источниках, сделан вывод о том, что исторический процесс совершенствования знаний о природе человека и его психической деятельности в последние годы достиг наивысшего уровня развития.

Изучение многолетнего опыта ученых многих стран мира позволяет утверждать, что начало процессу целенаправленного изучения влияния физической активности на психические функции человека было положено еще в прошлом веке. Однако за последние десятилетия ученые добились самых выдающихся результатов в этой области научных исследований.

Историческая потребность в тщательных исследованиях в этом научном направлении назревала постепенно и была обусловлена особенностями хода научно-технического прогресса в целом.

В связи с тем, что именно в последние десятилетия было сделано много открытий, которые легли в основу современных методов изучения физиологического состояния человека и его интеллектуальных функций, наметился очевидный прогресс в изучении психического здоровья лиц, центральная нервная система которых работает в условиях экстремального интеллектуального и психоэмоционального стресса.

Ученые, изучающие проблемы физического воспитания и спорта, в сотрудничестве с учеными в области образования и здравоохранения значительно активизировали свою совместную деятельность и разработали современные комплексы мероприятий, направленных на изучение психического здоровья студентов и представителей профессорскопреподавательского состава государственных высших учебных заведений.

Этот контингент испытуемых был выбран не случайно. Дело в том, что процесс обучения в высших учебных заведениях связан с интенсивными нагрузками на центральную нервную систему как студентов, так и преподавателей, а также на некоторые их органы чувств (в частности, на зрительный и слуховой анализаторы).

Ключевые слова: центральная нервная система, интеллектуальный стресс, когнитивные функции головного мозга, уровень психического здоровья. 